\title{
Pengaruh Penggunaan Teknologi Informasi Dan Media Sosial Terhadap Prestasi Belajar Mahasiswa
}

\author{
Ari Wibowo"); R. Arie Febrianto ${ }^{2)}$ \\ ${ }^{1)}$ Program Sudi: Sistem Informasi D3, STMIK Sinar Nusantara \\ 2) Program Sudi: Sistem Informasi Akuntansi D3, STMIK Sinar Nusantara \\ 1) ariwibowoy35@gmail.coml; ${ }^{2)}$ ariefebrianto337@gmail.com
}

\begin{abstract}
The objectives of this study are: (1) To measure and test the effect of the use of information technology and social media on student achievement in STMIK Sinar Nusantara Surakarta. (2)To measure and test the interaction of the use of information technology and social media on student achievement in STMIK Sinar Nusantara Surakarta. The numbers of samples in this study were 50 respondents. The sampling technique uses purposive sampling. The results of the regression analysis found that there is a positive and significant influence of the use of information technology and social media on the learning achievement of students majoring in STMIK Sinar Nusantara Surakarta. T test and F test results prove that the information technology and social media variables have positive and significant effects both partially and simultaneously on learning achievement. Based on the coefficient of determination with positive value of 0.397 shows that the learning achievement of students in STMIK Sinar Nusantara Surakarta can be explained by the information technology and social media variables with $39.7 \%$, while the remaining, $60.3 \%$, is explained by other factors which were not observed in this study.
\end{abstract}

Keywords: Information Technology, Social Media, Learning Achievement and Regression

\section{PENDAHULUAN}

Era teknologi seperti saat ini, fasilitas internet atau Wi-Fi telah menjamur dimanamana, tidak terkecuali di Perguruan Tinggi STMIK Sinar Nusantara Surakarta yang telah dilengkapi fasilitas Wi-Fi untuk mendukung kelancaran mahasiswa dalam belajar. Selain itu mahasiswa juga memiliki fasilitas teknologi informasi seperti laptop, smartphone ataupun gadget lainnya. Semua teknologi informasi tersebut mempunyai dampak positif dan dampak negatif yang tidak dapat dihindari. Sisi positif adanya semua fasilitas tersebut dapat membantu mahasiswa dalam mencari sumber belajar lain, untuk berdiskusi terkait materi perkuliahan serta menambah wawasan mahasiswa menjadi lebih luas, sehingga berdampak prestasi belajar mahasiswa akan meningkat. Namun tentu terdapat dampak negatif dari adanya fasilitas tersebut apabila tidak dapat menggunakannya dengan bijak seperti mahasiswa lebih memilih membuka situs yang disukai daripada yang berkaitan dengan perkuliahan. Apabila hal tersebut terjadi, maka waktu belajar akan habis tidak untuk belajar dan akibatnya prestasi belajar dapat menurun.

Banyaknya situs media sosial yang muncul memungkinkan para mahasiswa untuk berinteraksi dengan mudah dan dengan biaya yang murah dibandingkan dengan menggunakan telepon. Salah satu dampak positif yang lain dari adanya situs jejaring sosial adalah percepatan penyebaran informasi yang dapat mempermudah mahasiswa mendapat materi perkuliahan, Namun dari kemudahan yang ditawarkan media tersebut, terdapat sisi lain yang dapat merugikan penggunanya dan orang-orang disekitarnya, yakni berkurangnya interaksi interpersonal secara langsung atau tatap muka, munculnya kecanduan yang melebihi dosis, serta persoalan etika dan hukum karena kontennya yang melanggar moral, privasi serta peraturan.

Teknologi informasi dan media sosial yang dimanfaatkan dengan benar dan tepat akan berdampak positif untuk menambah pengetahuan mahasiswa sehingga diharapkan prestasi belajar mahasiswa meningkat. Sebaliknya pemakaian teknologi informasi dan media sosial yang tidak benar malah akan membuat prestasi belajar mahasiswa menurun. Guna mengetahui seberapa besar faktor-faktor tersebut mempengaruhi prestasi belajar mahasiswa maka diperlukan untuk melakukan penelitian dengan judul "Pengaruh Penggunaan Teknologi Informasi dan Media Sosial terhadap Prestasi Belajar Mahasiswa STMIK Sinar Nusantara Surakarta". 


\section{TINJAUAN PUSTAKA}

2.1. Teknologi Informasi

Pengertian informasi sering disamakan dengan pengertian data. Data adalah sesuatu yang belum diolah dan belum dapat digunakan sebagai dasar yang kuat dalam pengambilan keputusan. Beberapa gabungan data yang dipakai dalam pengambilan kesimpulan itulah yang disebut informasi. Teknologi informasi berupa hardware dan software komputer yang digunakan untuk melakukan tugas-tugas yang berhubungan dengan pemrosesan informasi. Jadi Teknologi informasi meliputi segala hal yang berkaitan dengan proses, penggunaan sebagai alat bantu, manipulasi, dan pengelolaan informasi [1].

\subsection{Media Sosial}

Media sosial adalah alat komunikasi yang digunakan oleh pengguna dalam proses sosial, berupa teknologi-teknologi web terbaru menggunakan internet yang memudahkan manusia untuk bisa berkomunikasi, berpartisipasi, saling berbagi ilmu dan membangun komunitas secara online, sehingga dapat menyebarluaskan konten mereka sendiri. Beberapa situs media sosial yang populer sekarang ini antara lain: Whatsapp, Twitter, Facebook, YouTube, dan Instagram [2].

\subsection{Prestasi Belajar}

Prestasi belajar adalah perubahan yang diperoleh mahasiswa setelah mengalami proses pembelajaran untuk mencapai tujuan pembelajaran yang diwujudkan dalam bentuk perbuatan. Perubahan ini biasanya dapat dilihat dari beberapa ranah, yaitu kognitif, afektif, dan psikomotorik pada diri mahasiswa, untuk mengetahui hasilnya dapat diukur melalui tes ataupun pengamatan secara langsung [3].

\subsection{Analisis Regresi Linier Berganda}

Teknik analisa data yang digunakan dalam penelitian ini adalah dengan menggunakan Ekonometrika model analisis regresi linier berganda yaitu untuk membuktikan pengaruh penggunaan teknologi informasi dan media sosial terhadap prestasi belajar mahasiswa STMIK Sinar Nusantara. Adapun rumus persamaan regresi linier berganda sebagai berikut :

$$
\begin{aligned}
& Y=a+b_{1} X_{1}+b_{2} X_{2}+e \\
& \text { di mana: } \\
& \mathrm{Y} \text { : prestasi belajar } \\
& X_{1} \text { : penggunaan teknologi informasi } \\
& \mathrm{X}_{2} \text { : penggunaan media sosial }
\end{aligned}
$$
a : konstanta
b : koefisien regresi
e : error term[4]

\subsection{Penelitian Terdahulu}

Penggunaan TIK mempunyai hubungan yang kuat dengan peningkatan penguasaan media internet para pendidik dalam memotivasi Peserta didik. Hal ini ditandai dengan nilai koefisien korelasi $\mathrm{R}=0,861$ (mendekati nilai angka 1). Artinya semakin diterpa penggunaan TIK pada mata pelajaran Bahasa Inggris maka semakin kuat peningkatan penguasaan media internet para pendidik dalam memotivasi Peserta didik kelas X SMA Negeri I Dekai Kabupaten Yahukimo [5].

Penelitian lain menguji pengaruh teknologi informasi terhadap prestasi akademik mahasiswa kelas akuntansi keuangan lanjutan. Populasi dalam penelitian ini adalah mahasiswa semester lima program studi pendidikan akuntansi IKIP PGRI Madiun. Jumlah sampel 126 mahasiswa. Hasil penelitian ini menunjukkan kemampuan mahasiswa dalam menggunakan aplikasi office dan penggunaan internet berpengaruh signifikan terhadap prestasi akademik mahasiswa [6].

Penelitian ini dilakukan di Sekolah Menengah Pertama Negeri 6 Kota Tasikmalaya dengan data penelitian tahun ajaran 2017/2018 dan data hasil kuesioner yang telah disebar kepada siswa siswi SMP Negeri 6 Kota Tasikmalaya. Dari data yang didapatkan tersebut dilakukan uji prasyarat analisis yaitu pengujian normalitas data dengan menggunakan uji Kolmogorov Smirnov. Sedangkan untuk pengujian hipotesis, metode analisis yang digunakan adalah Metode Korelasi Rank Spearman yang bertujuan untuk mengetahui pengaruh dari media sosial terhadap prestasi akademik siswa. Pengujian hipotesis dalam penelitian ini menggunakan uji dua pihak. Hasil penelitian ini menunjukkan bahwa nilai correlation coefisien adalah 0,960 atau $96 \%$ dan sig 0.00 ; 0.05 . Hal ini menunjukkan bahwa terdapat pengaruh yang sangat kuat antara media sosial (facebook dan instagram) terhadap prestasi akademik siswa SMP Negeri 6 Kota Tasikmalaya [7].

\section{METODE PENELITIAN}

Penelitian dilakukan dengan metode survey yaitu metode penelitian yang 
menggunakan kuesioner sebagai instrument utama untuk mengumpulkan data. Metode pengambilan data yang digunakan agar diperoleh sampel yang representatif adalah Purposive Sampling.

\subsection{Jenis Data}

a) Data Primer, yaitu data yang diperoleh dari lokasi penelitian secara langsung dari responden di STMIK Sinar Nusantara di Surakarta berjumlah 50 mahasiswa.

b) Data Sekunder, yaitu data yang diperoleh dengan cara membaca literatur yang berkaitan dengan masalah yang diteliti.

\subsection{Variabel Penelitian}

Variabel terikat adalah variabel yang nilainya terikat dan dipengaruhi oleh variabel bebas yang biasanya diberi notasi Y. Dalam penelitian ini variabel terikat prestasi mahasiswa STMIK Sinar Nusantara.

Variabel bebas adalah variabel yang menjadi penyebab timbulnya variabel terikat digunakan untuk menentukan hubungan antara fenomena yang sedang diamati, dalam penelitian ini terdiri dari dua variabel bebas $\mathrm{X}_{1}$ : penggunaan teknologi informasi dan $\mathrm{X}_{2}$ : penggunaan media sosial.

\subsection{Pemrosesan Data}

a) Proses Input Data

Setelah data diperoleh dari hasil penyebaran kuesioner yang dikembalikan, selanjutnya data dimasukkan dalam lembar kerja dan siap diolah dengan menggunakan perangkat lunak pengolah data statistik ( SPSS ).

b) Pengujian Validitas dan Reliabilitas Data Sebagai bagian dari persiapan awal untuk mengolah data lebih lanjut, maka perlu dilakukan pengujian validitas dan reliabilitas data.

c) Analisis Regresi Linier Berganda dan Uji Asumsi Klasik

Suatu persamaan regresi linier diperlukan uji asumsi klasik untuk menentukan bahwa model yang di peroleh tidak bias dan efisien yaitu memenuhi sifat BLUE /Best Liner Unbiased Estimation. Uji asumsi klasik terdiri dari tiga macam yaitu Multikolonieritas, Heteroskedastisitas, dan Normalitas.

d) Uji Hipotesis melingkupi koefisien determinasi, uji $\mathrm{F}$ dan uji t.
Kisi-kisi / indikator pada kuesioner untuk ketiga variabel penelitian tertera pada Tabel1.

\section{Tabel 1. Kisi-kisi Variabel Penelitian}

\begin{tabular}{|c|l|c|}
\hline Variabel & \multicolumn{1}{|c|}{ Indikator } & Butir \\
\hline & 1. Bahan Ajar & 1,3 \\
Teknologi & 2. Informasi Media & 2,5 \\
& 3. Referensi Belajar & 4 \\
\hline \multirow{4}{*}{ Media Sosial } & 1. Frekuensi & 1 \\
& \multicolumn{2}{|c|}{ Penggunaan } \\
& 2. Tugas Perkuliahan & 2,5 \\
& 3. Update Informasi & 3,4 \\
\hline \multirow{2}{*}{ Prestasi } & 1. Kognitif & 1,5 \\
Belajar & 2. Afektif & 3 \\
& 3. Psikomotorik & 2,4 \\
\hline
\end{tabular}

\subsection{Statistik Deskriptif}

Tabel 2. Jenis Kelamin Reponden

\begin{tabular}{|c|c|c|}
\hline \multirow{2}{*}{ Jenis Kelamin } & \multicolumn{2}{|c|}{ Responden } \\
\cline { 2 - 3 } & Jumlah & Persentase (\%) \\
\hline Perempuan & 20 & 40 \\
\hline Laki-laki & 30 & 60 \\
\hline Jumlah & 50 & 100 \\
\hline
\end{tabular}

Tabel 3. Statistik Desktiptif Variabel Penelitian

\begin{tabular}{|c|c|c|c|c|c|}
\hline Variabel & N & Min & Max & Mean & SD \\
\hline Tek. Informasi & 50 & 11,00 & 25,00 & 18,30 & 3,43 \\
\hline Media Sosial & 50 & 11,00 & 25,00 & 17,94 & 3,20 \\
\hline Prestasi Belajar & 50 & 12,00 & 24,00 & 18,12 & 2,82 \\
\hline
\end{tabular}

Terlihat nilai rata-rata tertinggi pada teknologi informasi dan terendah pada media sosial. Sedangkan keragaman nilai data tertinggi pada teknologi informasi dan terendah pada prestasi belajar.

\subsection{Uji Instrumen Penelitian}

a) Uji Validitas

Uji validitas digunakan untuk mengukur valid atau tidaknya suatu kuesioner. Suatu kuesioner dikatakan valid jika pertanyaan pada kuesioner mampu untuk mengungkapkan sesuatu yang akan diukur oleh kuesioner tersebut.

Suatu item dikatakan valid jika $p$ value < 0,05 , dan sebaliknya apabila $p$ value $>0,05$ maka item tersebut tidak valid. Pengujian validitas dalam penelitian ini menggunakan pearson correlation dengan bantuan program SPSS dengan hasil seperti Tabel 4.

\section{HASIL DAN PEMBAHASAN}


Tabel 4 Hasil Uji Validitas

\begin{tabular}{|c|c|c|c|}
\hline Pertanyaan & $p$ value & $\alpha 0,05$ & Ket. \\
\hline P1 & 0,000 & 0,05 & Valid \\
P2 & 0,000 & 0,05 & Valid \\
P3 & 0,000 & 0,05 & Valid \\
P4 & 0,000 & 0,05 & Valid \\
P5 & 0,000 & 0,05 & Valid \\
\hline
\end{tabular}

Ketiga variabel hasil uji validitasnya sama seperti di Tabel 4 jadi semua kuisioner dinyatakan valid karena $p$ value $<0,05$.

b) Uji Reliabilitas

Uji reliabilitas digunakan untuk mengukur suatu kuesioner yang merupakan indikator dari variabel atau konstruk suatu kuesioner, disebut reliabel atau handal apabila jawaban seseorang atas pertanyaan adalah konsisten. Pengujian reliabilitas pada penelitian ini menggunakan alat ukur Cronbach's Alpha, apabila nilai Cronbach's Alpha > 0,60, maka instrumen tersebut reliabel.

Tabel 5 Hasil Uji Reliabilitas

\begin{tabular}{|c|c|c|c|}
\hline Variabel & $\begin{array}{c}\text { Cronbac } \\
\text { h's Alpha }\end{array}$ & $\begin{array}{c}\text { Nilai } \\
\text { Kritis }\end{array}$ & $\begin{array}{c}\text { Ketera } \\
\text { ngan }\end{array}$ \\
\hline Tek. Informasi & 0,730 & 0,60 & Reliabel \\
Media Sosial & 0,693 & 0,60 & Reliabel \\
Prestasi Belajar & 0,649 & 0,60 & Reliabel \\
\hline
\end{tabular}

Hasil uji reliabilitas menunjukkan bahwa nilai cronbach's alpha untuk semua variabel > nilai kritis $(0,60)$, maka dalam penelitian ini dikatakan reliabel.

\subsection{Analisis Regresi Linier Berganda dan Uji Asumsi Klasik}

a) Analisis Regresi Linier Berganda

Tabel 6 Hasil Uji Regresi Linier Berganda

\begin{tabular}{|c|c|c|c|c|}
\hline \multirow{2}{*}{ Model } & \multicolumn{2}{|c|}{$\begin{array}{c}\text { Unstandardized } \\
\text { Coefficients }\end{array}$} & \multirow{2}{*}{ Sig. } \\
\cline { 3 - 4 } \multicolumn{2}{|c|}{} & B & Std. Error & \\
\hline \multirow{2}{*}{1} & (Constant) & 7,353 & 1,981 & 0,001 \\
\cline { 2 - 5 } & Tek. Inform & 0,343 & 0,116 & 0,005 \\
\cline { 2 - 5 } & Media Soaial & 0,251 & 0,124 & 0,049 \\
\hline
\end{tabular}

a. Dependent Variabel : Prestasi Belajar

Dari hasil tersebut diketahui persamaan regresi linier berganda:

$Y=7,353+0,343 X_{1}+0,251 X_{2}+e$

$b_{1}=0,343$ bertanda positif, berarti jika penggunaan teknologi informasi $\left(X_{1}\right)$ naik satu satuan maka prestasi belajar (Y) mahasiswa STMIK Sinar Nusantara juga mengalami peningkatan sebesar 0,343 dengan asumsi variabel penggunaan media sosial dianggap tetap.

$b_{2}=0,251$ bertanda positif, berarti jika penggunaan media sosial $\left(\mathrm{X}_{2}\right)$ naik satu satuan maka prestasi belajar (Y) mahasiswa STMIK Sinar Nusantara juga akan mengalami peningkatan sebesar 0,251 dengan asumsi variabel penggunaan teknologi informasi dianggap tetap.

b) Uji Asumsi Klasik

\section{Uji Multikolonieritas}

Pengujian multikolonieritas dapat diketahui melalui nilai tolerance dan nilai Variance Inflation Factor (VIF). Jika tolerance value $>0,10$ dan nilai VIF kurang dari 10, maka dapat dikatakan tidak terjadi multikolinieritas.

\section{Tabel 7 Hasil Uji Multikolinearitas}

\begin{tabular}{|c|c|c|c|}
\hline Variabel & Toleran & VIF & Keterangan \\
\hline $\begin{array}{c}\text { Teknologi } \\
\text { Informasi }\end{array}$ & 0,643 & 1,56 & $\begin{array}{c}\text { Bebas } \\
\text { Multikolonieritas }\end{array}$ \\
\hline $\begin{array}{c}\text { Media } \\
\text { Sosial }\end{array}$ & 0,643 & 1,56 & $\begin{array}{c}\text { Bebas } \\
\text { Multikolonieritas }\end{array}$ \\
\hline
\end{tabular}

Hasil uji multikolinearitas diperoleh hasil bahwa variabel teknologi informasi dan media sosial nilai tolerance $>0,10$ dan nilai VIF < 10. berarti tidak terjadi multikolinearitas, maka regresi atau model yang digunakan dalam penelitian ini bebas multikolinearitas.

\section{Uji Heteroskedastisitas}

Uji heteroskedastisitas bertujuan untuk mengetahui apakah dalam model regresi terjadi ketidaksamaan variance dari residual satu pengamatan ke pengamatan yang lain. Jika sama disebut homoskedastisitas dan jika berbeda disebut heteroskedastisitas. Model regesi yang baik adalah homoskedastisitas atau tidak terjadi heteroskedastisitas. Untuk menguji ada tidaknya heteroskedastisitas di dalam penelitian ini menggunakan uji Glejser yaitu dengan cara meregresikan nilai absolute residual terhadap variabel independen.

Ada tidaknya heteroskedastisitas diketahui dengan melihat probabilitasnya terhadap derajat kepercayaan 5\%. Jika nilai probabilitas $>0,05$ maka tidak terjadi heteroskedastisitas. 
Tabel 8 Hasil Uji Heteroskedastisitas

\begin{tabular}{|c|c|c|l|}
\hline Variabel & $\mathrm{t}$ & Sig & \multicolumn{1}{|l|}{ Keterangan } \\
\hline $\begin{array}{c}\text { Teknologi } \\
\text { Informasi }\end{array}$ & $-0,93$ & 0,36 & $\begin{array}{l}\text { Bebas heteros } \\
\text { kedastisitas }\end{array}$ \\
\hline $\begin{array}{c}\text { Media } \\
\text { Sosial }\end{array}$ & 0,41 & 0,68 & $\begin{array}{l}\text { Bebas heteros } \\
\text { kedastisitas }\end{array}$ \\
\hline
\end{tabular}

Hasil uji heterokedastisitas dengan uji glejser diketahui bahwa variabel teknologi informasi dan media sosial $p$ value ( Sig.) > 0,05 maka tidak terjadi heteroskedastisitas.

\section{Uji Normalitas}

Uji Normalitas digunakan mengetahui normalitas data. Uji statistik yang digunakan Kolmogorov-Smirnov. Kriteria yang digunakan adalah dengan melihat hasil Sig $(p)$, jika Sig $(p)>0,05$ berarti sebaran data dalam distribusi adalah sesuai kurva normal, sehingga lolos uji normalitas, sebaliknya jika Sig ( $p), \leq 0,05$ berarti sebaran data dalam distribusi adalah tidak sesuai kurva normal, sehingga tidak lolos uji normalitas.

Tabel 9 Hasil Uji Normalitas

\begin{tabular}{|c|c|}
\hline \multicolumn{2}{|c|}{ One-Sample Kolmogorov-Smirnov Test } \\
\hline $\mathrm{N}$ & Unstandard. Residual \\
\hline $\begin{array}{c}\text { Kolmogorov- } \\
\text { Smirnov Z }\end{array}$ & 0,629 \\
\hline $\begin{array}{c}\text { Asymp. Sig. } \\
\text { (2-tailed) }\end{array}$ & 0,824 \\
\hline
\end{tabular}

Dari hasil uji normalitas menunjukkan bahwa $p$ value (Sig.) > 0,05 berarti bahwa data terdistribusi normal.

\subsection{Uji Hipotesis}

a) Koefisien Determinasi

Koefisien determinasi $\left(R^{2}\right)$ adalah perbandingan antara variabel prestasi belajar yang dijelaskan oleh variabel teknologi informasi dan media sosial secara bersama-sama.

Tabel 10 Hasil Koefisien Determinasi

\begin{tabular}{|c|c|c|}
\hline \multicolumn{3}{|c|}{ Model Summary } \\
\hline$R$ & $R$ Square & $\begin{array}{c}\text { Std. Error of the } \\
\text { Estimate }\end{array}$ \\
\hline $0,630 a$ & 0,397 & 2,23469 \\
\hline
\end{tabular}

Berdasarkan hasil perhitungan koefisien determinasi diperoleh nilai $R^{2}=0,397$, berarti dapat diketahui bahwa pengaruh variabel teknologi informasi dan media sosial berpengaruh terhadap prestasi belajar sebesar $39,7 \%$ sedangkan sisanya $60,3 \%$ dipengaruhi oleh faktor lain yang tidak diteliti.

b) Uji $F$

Uji $F$ digunakan untuk mengetahui ada tidaknya pengaruh variabel teknologi informasi dan media sosial secara bersama-sama terhadap prestasi belajar.

Tabel 11 Nilai Uji F ( ANOVA)

\begin{tabular}{|c|c|c|c|c|c|}
\hline & Sum2 & Df & $\begin{array}{c}\text { Mean } \\
\text { Square }\end{array}$ & $F$ & Sig. \\
\hline Regression & 154,57 & 2 & 77.28 & 15,48 & 0,000 \\
\hline Residual & 234,71 & 47 & 4,99 & & \\
\hline Total & 389,28 & 49 & & & \\
\hline
\end{tabular}

Hasil perhitungan dapat diperoleh nilai signifikansi $0,000<0,005$ sehingga Ho ditolak, variabel teknologi informasi dan media sosial secara bersama-sama berpengaruh terhadap prestasi belajar mahasiswa STMIK Sinar Nusantara.

c) Uji t

Uji $t$ adalah pengujian koefisien regresi individual untuk mengetahui kemampuan dari masing-masing variabel (teknologi informasi dan media sosial) dalam mempengaruhi variabel prestasi belajar dengan menganggap variabel lain konstan atau tetap.

Tabel 12 Nilai Uji t

\begin{tabular}{|c|c|c|c|}
\hline Variabel & $\begin{array}{c}\text { Koef. } \\
\text { regresi }\end{array}$ & $p$ value & Kesimpulan \\
\hline Tek.Informasi & 0,343 & 0,005 & Ha diterima \\
\hline Media Sosial & 0,251 & 0,049 & Ha diterima \\
\hline
\end{tabular}

Hasil perhitungan diperoleh dengan $\mathrm{p}$ value $0,005<0,05$ berarti teknologi informasi berpengaruh positif dan signifikan terhadap prestasi belajar mahasiswa STMIK Sinar Nusantara.

Hasil perhitungan diperoleh dengan $p$ value $0,049<0,05$ berarti media sosial berpengaruh positif dan signifikan terhadap prestasi belajar mahasiswa STMIK Sinar Nusantara.

\section{PENUTUP}

5.1. Kesimpulan

1. Nilai koefisien regresi variabel teknologi informasi lebih besar dibanding koefisien media sosial artinya variabel penggunaan teknologi informasi merupakan variabel 
yang paling dominan pengaruhnya terhadap prestasi belajar mahasiswa STMIK Sinar Nusantara.

2. Hasil penelitian menunjukkan bahwa penggunaan teknologi informasi berpengaruh positif dan signifikan terhadap prestasi belajar, semakin meningkatnya penggunaan teknologi informasi maka prestasi belajar mahasiswa juga mengalami peningkatan. Penggunaan media sosial yang berkualitas maka prestasi belajar mahasiswa akan semakin baik.

\subsection{Saran}

1. Mahasiswa perlu membiasakan dan menggunakan teknologi informasi dan media sosial secara tepat, benar dan bertanggungjawab karena mampu meningkatkan prestasi belajar.

2. Peneliti selanjutnya bisa melakukan penelitian tentang faktor-faktor yang dapat mempengaruhi prestasi belajar mahasiswa lainnya misal model pembelajaran $e$ learning, kemudahan akses internet, dan kecepatan internet-wifi.

\section{DAFTAR PUSTAKA}

[1] H. Budiman, "Peran Teknologi Informasi Dan Komunikasi Dalam Pendidikan," Al-Tadzkiyyah J. Pendidik. Islam, vol. 8, no. 1, p. 31, 2017, doi: 10.24042/atjpi.v8i1.2095.

[2] M. Mulawarman and A. D. Nurfitri, "Perilaku Pengguna Media Sosial beserta Implikasinya Ditinjau dari Perspektif Psikologi Sosial Terapan," Bul. Psikol., vol. 25, no. 1, pp. 36-44, 2017, doi: 10.22146/buletinpsikologi.22759.

[3] Noor Komari Pratiwi, "Pengaruh Tingkat Pendidikan, Perhatian Orang Tua, Dan Minat Belajar Siswa Terhadap Prestasi Belajar Bahasa Indonesia Siswa Smk Kesehatan Di Kota Tangerang," J. Pujangga, vol. Vol. 1, no. No 2, p. 75105., 2015.

[4] R. Wijaya, "Analisis Korelasi dan Regresi Sederhana," no. July 2014, pp. 1-11, 2010.

[5] Y. Yusri, "Pengaruh Penggunaan Media Teknologi Informasi dan Komunikasi (TIK) dengan Prestasi Belajar Bahasa Inggris Peserta Didik Kelas X di SMAN I Dekai Kabupaten Yahukimo," Ilk. J. Ilm., vol. 8, no. 1, pp. 49-56, 2016, doi: 10.33096/ilkom.v8i1.22.49-56.

[6] A. L. Wijaya, "Pengaruh penggunaan teknologi informasi terhadap prestasi akademik mahasiswa," no. 2009.

[7] T. Wibisono, "Analisis Dampak Penggunaan Media Sosial," Ekon. Manaj., vol. 4, no. 1, pp. 1-7, 2018. 